\title{
$\mathrm{Ku}$ 대역 위성통신용 타일형 수신 위상배열 안테나의 설계
}

\section{Design of Tile-Type Rx Phased-Array Antenna for Ku-Band Satellite Communications}

\author{
주 태 환·김 기 철·서 종 우 \\ Taehwan Joo $\cdot$ Kichul Kim $\cdot$ Jongwoo Seo
}

요 약

본 논문에서는 Ku대역 위성 통신을 위한 타일형 수신 위상 배열안테나의 설계, 제작 및 성능시험 결과에 대해 기술하였다. 본 타일형 수신 위상 배열안테나는 3장의 다층기판으로 구성된다. 첫 번째 기판은 $8 \times 8$ 배열의 패치안테나 및 저잡음 증폭기, 위상 천이기를 포함한 코어칩으로 구성되어 있으며, 두 번째 기판은 증폭기 및 빔 편이오차를 최소화하기 위한 TTD(True Time Delay) 회로를 포함한다. 세 번째 기판은 빔 지향을 위한 위상 천이기 및 TTD의 제어부와 신호 결합기로 구성된다. 제작된 안테 나의 크기는 약 $33 \times 96 \times 96 \mathrm{~mm}^{3}$ 이며 $250 \mathrm{~g}$ (하우징 포함) 수준의 무게를 갖는다. 안테나의 전기적 성능시험 결과, $\mathrm{Ku}$ 대역 동작 주파수의 중심에서 약 $24 \mathrm{dBi}$ 의 이득 및 $12^{\circ}$ 빔폭을 나타내었다. 또한 동작 대역폭인 $500 \mathrm{MHz}$ 에서 phi 방향 $0^{\circ}$ theta 방향 $40^{\circ}$ 빔지향시 전 대역에서 $1^{\circ}$ 이하의 빔 편이오차로 빔 지향 가능함을 확인하였다. 본 논문에서 제안한 타일의 다수 결합을 통해 $\mathrm{Ku}$ 대역의 위성통신이 가능하며 다양한 형상에 적응 가능한 컨포멀 안테나를 구성할 수 있다.

\begin{abstract}
In this paper, we describe the design, manufacture, and performance test results of a highly integrated tile-type Rx phased-array antenna for Ku-band satellite communication. The designed tile-type receive phased-array antenna is composed of three multilayer boards. The first board consists of $8 \times 8$ arrayed patch antennas and a core chip with a low-noise amplifier and phase shifters. The second board includes a true time delay(TTD) circuit to minimize the beam squint in the wide frequency band and amplifiers. The third board consists of circuits to control the phase shifters and TTD circuit in boards 1 and 2, respectively. The manufactured tile-type antenna has the size and weight of $33 \times 96 \times 96 \mathrm{~mm}^{3}$ and $250 \mathrm{~g}$, respectively. The results of the electrical performance test of the antenna are that the antenna gain and beam width are $24 \mathrm{dBi}$ and $12^{\circ}$ at the center of the operating frequency in the Ku-band. Further, the beam squint performance is less than $1^{\circ}$ when steering through $0^{\circ}$ and $40^{\circ}$ in the $\phi$ and $\theta$ directions, respectively. A conformal phased-array antenna can be produced for satellite communication in the Ku-band using the proposed tile antenna.
\end{abstract}

Key words: Tile Type, Rx Tile, Phased Array Antenna, Conformal Antenna, Satellite Communication

\section{I. 서 론}

최근 무인기 탑재 고성능 정보획득 센서의 증가로 대 용량 데이터링크를 위한 기존의 저속 조향시스템 대신

\footnotetext{
국방과학연구소 제2기술연구본부(The $2^{\text {nd }}$ Research and Development Institute, Agency for Defense Development)

- Manuscript received August 13, 2019 ; Revised September 16, 2019 ; Accepted September 27, 2019. (ID No. 20190813-076)

· Corresponding Author: Taehwan Joo (e-mail: e-mail: jooth01@gmail.com)
} 
고속 전자식 빔 조향 시스템의 필요성이 대두되고 있다. 특히 군수분야의 무인기 등의 운항효율 증가, 구조 무게 감소, 항공기 순항 에너지 소모 감소 등을 위하여 형상적 응형 안테나의 필요성이 증대되고 있다.

그림 1 에서 위상배열안테나의 송/수신 모듈을 구성하 는 방법에는 타일형 구조와 브릭형 구조를 나타내었다. 타일형 구조는 신호 전송방향과 시스템 모듈 적층 방향 이 동일하며, 브릭형 구조는 신호 전송방향과 평행한 방 향으로 시스템 모듈이 구성된다. 타일형 구조는 하나의 기판에 신호 송수신을 위한 소자를 장착하지 않고, 3 차원 구조로 다수의 기판에 송수신을 위한 소자를 장착하므로, 일반적으로 브릭형 구조의 안테나에 비해 얇은 배열 안 테나의 구성이 가능하다. 하지만, 타일형 안테나는 높은 집적도로 인해 구현 복잡성이 크게 증가하며, 좁은 배열 간격의 문제로 열문제 등이 심각하게 발생되어 구현 난 이도가 높다 ${ }^{[1]}$.

집적도와 열문제 등의 해결을 위해 타일형 배열안테나 에서 부배열 구조, 전자-기계적 구동부 연동 빔조향, $\mathrm{OBFN}$ (Optical Beam-Forming Network) 구조 적용 등 높은 집적 에 의한 열문제를 해결하려는 시도가 있었다 ${ }^{[5] ~[7]}$. 하지 만, 부배열 구조는 그레이팅 로브 증가등의 단점이 있으 며, 전자-기계적 구동부 및 $\mathrm{OBFN}$ 구조는 실제 운용환경 적용성(빔추적속도 및 정확도, 탑재 무게 증가 등) 단점이 존재한다.

이러한 제약사항으로 인해 대형 위상배열안테나 시스 템에서는 주로 브릭형 구조를 채택하고 있지만, 적용 플랫 폼의 다양한 형상에 적응 가능한 안테나를 설계하기 위 해서는 타일형 안테나 기술이 필수적이며, 이를 위해 국 내외에서 지속적으로 연구가 진행되고 있다 ${ }^{[2]-[9]}$.

또한 고속 데이터 전송을 위해서는 넓은 대역폭의 신 호를 송/수신할 수 있는 특성이 요구되지만, 위상배열 안 테나에서 일반적인 위상 천이기만을 이용할 경우 주파수 에 따른 빔 편이 형상이 발생하며, 이는 빔 지향 오차를 증가시키게 된다. 따라서 넓은 대역폭의 신호로 송/수신 할 때 주파수에 따른 빔 편이 현상을 제거 또는 최소화 할 수 있는 배열 안테나의 설계가 요구된다 ${ }^{[10] ~[12] . ~}$

본 논문은 위성통신에 적용 가능한 광대역 신호에 낮은 빔 편이 현상을 갖는 타일구조의 수신형 위상배열 안테

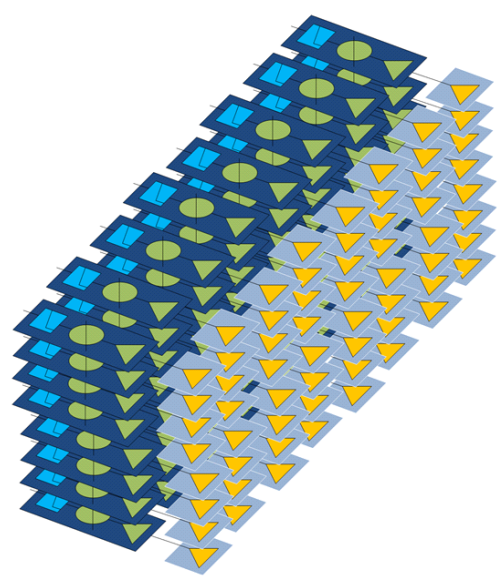

(a) 브릭형 배열 안테나 구조

(a) Brick type array antenna

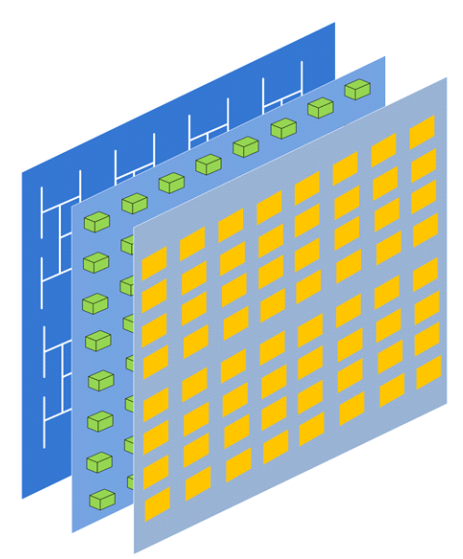

(b) 타일형 배열 안테나 구조

(b) Tile type array antenna

그림 1. 브릭형 및 타일형 위상배열 안테나의 구조 비교 Fig. 1. Comparison of brick and tile type phased array antenna.

나를 제시하였다. 2장에서는 타일구조의 수신 위상배열 안테나의 설계 사항을 기술하였으며, 3장은 타일형 수신 위 상배열 안테나의 제작 및 측정 결과에 대해 기술하였다.

\section{II. 타일형 수신 위상배열 안테나의 설계}

\section{2-1 타일형 수신 위상배열 안테나 설계 목표}

위성 통신을 위해서는 약 $10 \mathrm{~dB} / \mathrm{K}$ 이상의 $\mathrm{G} / \mathrm{T}$ (Antenna Gain to Noise Temperature)가 요구된다. 이는 본 타일형 안 
표 1. 수신 타일형 위상 배열 안테나의 설계 목표 Table 1. Design specification of Rx tile array antenna.

\begin{tabular}{|c|c|c|c|}
\hline \multicolumn{2}{|c|}{ Item } & Freq. band & Design target \\
\hline \multirow{2}{*}{$\begin{array}{l}\text { Max. steering } \\
\text { angle }\end{array}$} & phi & \multirow{2}{*}{$\mathrm{Ku}$} & $0 \sim 360^{\circ}$ \\
\hline & theta & & $0 \sim 60^{\circ}$ \\
\hline \multicolumn{2}{|c|}{ Operating frequency } & $\mathrm{Ku}$ & $\begin{array}{c}500 \mathrm{MHz} \\
f_{L}=f_{C}-250 \mathrm{MHz} \\
f_{H}=f_{C}+250 \mathrm{MHz}\end{array}$ \\
\hline \multicolumn{2}{|c|}{ Antenna gain } & $\mathrm{Ku}$ & $>21.2 \mathrm{dBiL}$ \\
\hline \multicolumn{2}{|c|}{ Antenna beamwidth } & $\mathrm{Ku}$ & $<14^{\circ}$ \\
\hline \multicolumn{2}{|c|}{ Beam pointing error } & $\mathrm{Ku}$ & $<5.6^{\circ}$ \\
\hline \multicolumn{2}{|c|}{ Noise figure } & $\mathrm{Ku}$ & $<3 \mathrm{~dB}$ \\
\hline
\end{tabular}

테나의 연속배열로 이루어지며, 이를 만족하기 위한 개별 수신 타일 안테나 성능 지표에서 안테나 이득은 $21.1 \mathrm{dBiL}$ 이상이며, 빔폭은 $14^{\circ}$ 이하이다. 또한 수신 잡음지수는 3 $\mathrm{dB}$ 이하 및 지향오차는 $5.6^{\circ}$ 이하 요구된다. 표 1 은 수신 타일형 안테나의 설계 목표를 나타낸다.

\section{2-2 타일형 수신 위상배열 안테나 구성도}

그림 2는 수신 타일형 안테나의 구성도를 나타낸다. 위 성으로부터 수신된 신호의 증폭, 결합, 주파수 변환 및 빔 지향을 위한 회로들로 구성 있으며, 이를 타일 내부 3장

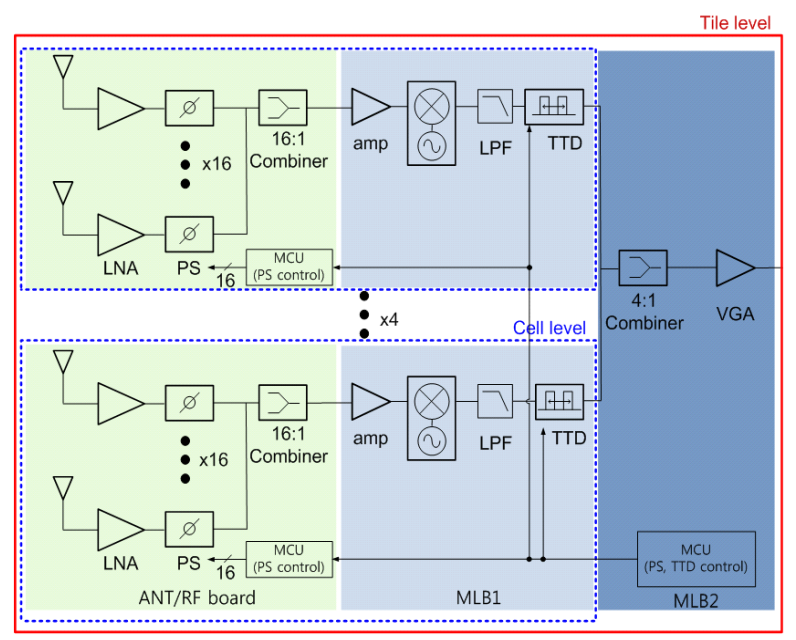

그림 2. 수신 타일 배열 안테나 구조도

Fig. 2. Block diagram of Rx tile phased array antenna.
의 보드에 3차원 구조로 나누어 배치하였다. 구성된 보드 는 안테나/RF 보드, 1차, 2차 MLB(Multi-Layer Board)로 나누어진다.

하나의 수신 타일은 4개의 셀로 구성된다. 셀은 안테나/ $\mathrm{RF}$ 보드와 1 차 MLB에 분리 구성된다. 이의 위상 및 $\mathrm{TTD}$ (True Time Delay)의 제어를 위한 MCU(Micro-controller Unit)가 안테나/RF 보드 및 2차 MLB에 각각 설계되었다. 셀 레벨 구현을 위해 16 개의 저잡음 증폭기, 위상천이기 및 하나의 $16: 1$ 결합기가 안테나/RF 보드에 설계하였다. 이의 증폭, 주파수 변환 및 시간 지연을 위한 소자가 1차 $\mathrm{MLB}$ 에 설계되었다.

설계된 수신 타일 안테나는 64개의 $\mathrm{Ku}$ 대역 입력 신호 를 결합하여 1 개의 L대역 출력신호를 생성한다. 타일 안 테나의 신호 증폭 및 결합을 통해 약 $100 \mathrm{~dB}$ 의 이득을 갖 는다. 위성으로부터 개별 안테나로 $\mathrm{Ku}$ 대역 입력신호가 $-150 \mathrm{dBm}$ 인 경우, 수신 타일의 최대 이득일 때 전력 출 력은 다음과 같다. 저잡음 증폭기 및 $16: 1$ 결합기를 통한 안테나/RF 보드의 출력은 약 $-130 \mathrm{dBm}$ 이며, 주파수 변 환 및 $\mathrm{TTD}$ 를 통한 1 차 $\mathrm{MLB}$ 의 L대역 출력은 약 $-80 \mathrm{dBm}$ 이다. 설계된 $\mathrm{VGA}($ Variable Gain Amplifier) 및 4:1 결합기 를 통한 타일의 최종 출력은 약 $-50 \mathrm{dBm}$ 이다.

\section{2-3 안테나/RF 보드 설계}

수신 안테나는 패치 안테나 구조로 슬롯 커플링 급전을 통해 $\mathrm{Ku}$ 대역 주파수에 접합한 광대역 특성을 확보하였 고, 수직/수평 편파 및 원형 편파 특성을 위하여 두 개의 급전 구조를 가지도록 설계하였다.

마이크로스트립 패치안테나가 존재하는 기판은 저유전 율의 Teflon 재질 $(\varepsilon=2.2)$ 의 $1.02 \mathrm{~mm}$ 두께를 사용하였고, feed-line이 존재하는 기판은 고유전율의 로져스 기판 $(\varepsilon=$ $3.35)$ 두께 $0.51 \mathrm{~mm}$ 를 사용하여 feed-line 폭을 줄여 공간 을 확보하였다. 그림 3(a)에 단일 복사소자의 설계를 나타 내었다. 그림 $3(\mathrm{~b})$ 는 단일 복사소자의 $8 \times 8$ 배열 안테나 구 성을 나타낸다. $\mathrm{Ku}$ 대역 운용 주파수를 맞추기 위하여 개 별 패치안테나는 $6 \mathrm{~mm}$ 로 설계하였으며, 안테나간 간격은 $\lambda / 2$ 인 $12 \mathrm{~mm}$ 로 안테나를 배열하였다. 단일 패치안테나 의 반사계수는 $-18.2 \mathrm{~dB}$ 를 갖도록 설계하였다. 설계된 


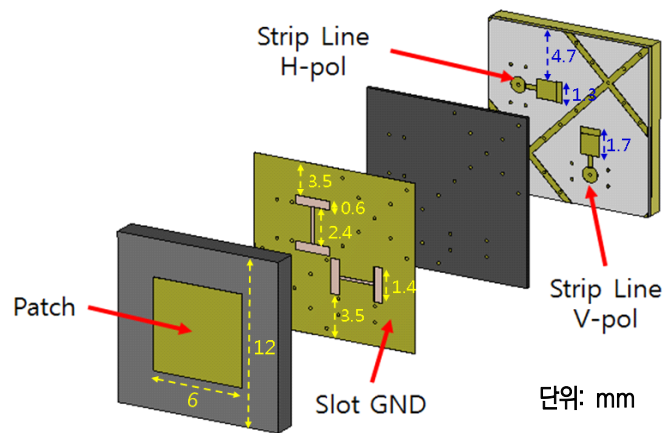

(a) 단일 복사소자의 설계 개념도

(a) Design concept of unit radiating antenna
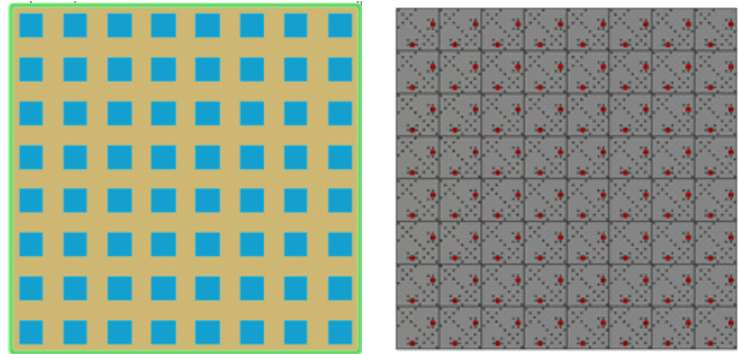

(b) $8 \times 8$ 배열 안테나의 설계

(b) Design of $8 \times 8$ array antenna

그림 3. 수신 타일의 안테나부 설계

Fig. 3. Design of array antenna in Rx tile.

배열 안테나의 시뮬레이션 결과는 앙각 $0^{\circ}$ 일 때 $-15 \mathrm{~dB}$ 를 나타내었으며, 최대 지향각인 $60^{\circ}$ 앙각에서는 주파수 에 따라 $-7.2 \sim-10 \mathrm{~dB}$ 의 active return loss를 나타내었다. 개별 안테나의 VSWR(Voltage Standing Wave Ratio)는 운 용주파수에서 1.2 1.5 dB를 갖도록 설계하였다.

그림 4는 $\mathrm{RF}$ 기판의 설계를 나타낸다. $\mathrm{RF}$ 기판은 저잡 음 증폭기, 위상천이기와 이의 제어용 $\mathrm{SPC}(\mathrm{Serial}$ to $\mathrm{Pa}-$ rallel Converter)가 집적된 코어칩과 이의 제어신호 생성 을 위한 $\mathrm{MCU}$ 및 수신 신호를 결합하기 위한 $16: 1$ 결합기 로 주요 구성되었다. V-pol, H-pol의 선형 및 원형 편파를 지원하기 위해 개별 안테나에 2개의 수신 경로가 필요하 므로 총 128 개의 코어칩을 RF보드에서 배치하였다. 개별 코어칩은 $\mathrm{Ku}$ 동작 대역에서 이득 $10 \mathrm{~dB}$, 수신잡음 $2 \mathrm{~dB}$ 및 4 bit 위상천이가 가능하도록 설계되었다. 코어칩의 위 상제어를 위해 $\mathrm{RF}$ 보드에 $\mathrm{MCU}$ 를 8 개 배치하였으며, 1 개 의 $\mathrm{MCU}$ 에서 16 개의 코어칩을 제어한다.

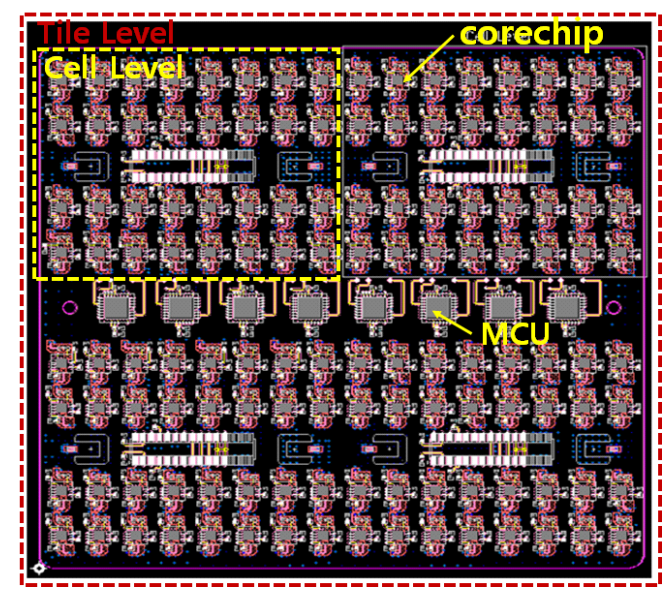

그림 4. 수신 RF보드의 설계

Fig. 4. Design of Rx RF board.

$\mathrm{RF}$ 기판은 Rogers사의 RO4350B, RO4450B, RO4003C 그리고 FR4로 이루어진 23층 기판으로 구성되었다. $\mathrm{RF}$ 기판의 상면에 코어칩과 $\mathrm{MCU}$ 가 부착되며, $16: 1$ 결합기는 기판 내부 2 층을 이용하여 구성되었다.

설계된 16:1 신호 결합기는 면적 최소화를 위해 T-junction 구조로 설계하였으며, 시뮬레이션된 $16: 1$ 결합기의 삽입손실 결과는 약 $-2.5 \mathrm{~dB}$ 이다. 이의 설계를 그림 $5(\mathrm{a})$ 에 나타내었다. 그림 5(b)는 RF 보드의 상부면을 나타낸다. $\mathrm{RF}$ 보드 상부면에는 V-pol, H-pol을 동시 동작하기 위한 안 테나 피딩부가 설계되어 있으며, 안테나보드와의 접합을 통해 패치안테나를 구동하게 된다. 접합면의 격자무늬는 안테나 피딩부간의 간섭을 최소화하기 위한 접지면이다. $\mathrm{RF}$ 기판과 안테나 기판은 서로 접합으로 구성된다. 따 라서 안테나/RF 보드 상면은 패치안테나로 구성되며, 하 부면은 코어칩 및 MCU가 배치된다. 수신 타일안테나 내 부에서 신호 흐름도를 그림 6에 나타내었다. 개별 패치 안테나에서 수신된 신호가 저잡음증폭기와 위상천이기 가 집적화된 코어칩으로 전달되며, $16: 1$ 신호결합기를 통 해 결합된다. 이는 커넥터를 통해 1차 MLB로 전달된다. MLB 상, 하면에 부착된 소자를 통해 그림 2의 신호 경로 를 통해 처리되도록 설계하였다. $\mathrm{RF} /$ 안테나 보드 상하면 23 층 전달에 의한 안테나 피딩 손실은 약 $0.5 \mathrm{~dB}$ 이다. 안 테나/RF보드 결합 상태에서의 두께 및 크기는 $5.5 \times 96 \times 96$ $\mathrm{mm}^{3}$ 이다. RF보드의 두께 및 크기는 약 $4 \times 96 \times 96 \mathrm{~mm}^{3}$ 이며, 


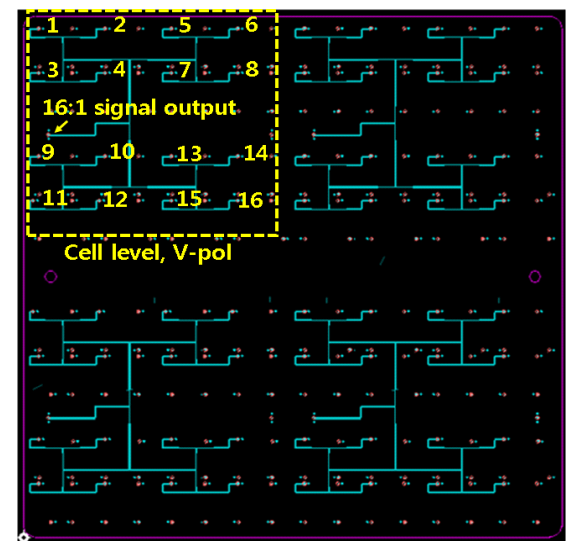

(a) $16: 1$ 신호 결합기(V-pol) 설계

(a) Design of 16:1 signal combiner(V-pol)

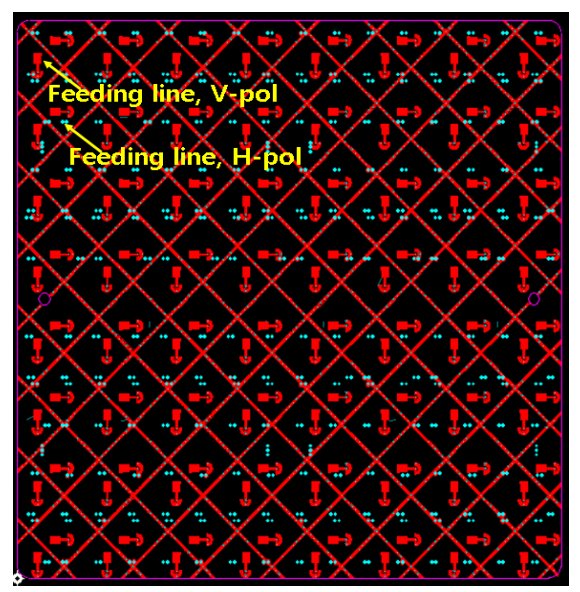

(b) 안테나-RF 보드 접합면 설계

(b) Design of antenna - RF board attachment

그림 5. 수신 타일의 RF기판 설계

Fig. 5. Design of RF board in Rx tile.

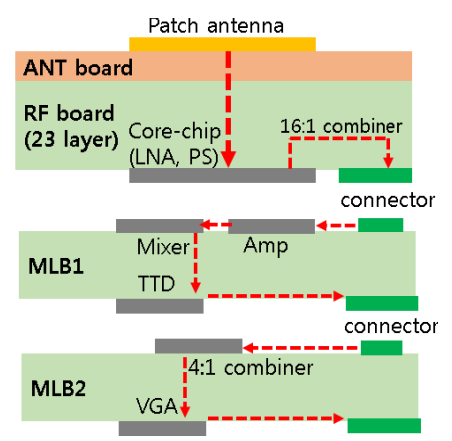

그림 6. 수신 타일 내부 신호 흐름도

Fig. 6. RF signal flow in Rx tile ANT.
셀의 크기는 이의 $1 / 4$ 인 $4 \times 46 \times 46 \mathrm{~mm}^{3}(\mathrm{MCU}$ 포함)이다.

\section{2-4 1차 MLB 설계}

1 차 $\mathrm{MLB}$ 의 주요 기능은 안테나/RF보드에서 증폭 및 위상 천이된 $\mathrm{Ku}$ 대역 신호를 받아서 IF 대역인 L대역으 로 주파수 변환 후 TTD(True Time Delay) 소자를 이용하 여 광대역 빔 편이 없이 빔 지향제어를 한다. 본 타일형 안테나는 위성통신을 위해 수신 전대역 약 $500 \mathrm{MHz}$ 를 지 원 가능하도록 설계해야 한다.

따라서 광대역에서 주파수 빔 편이 현상을 최소화하며, 광각의 빔 지향 성능을 $\mathrm{Ku}$ 대역의 위상천이기와 L대역 의 TTD를 혼합 구성하였다. 배열안테나에서 TTD의 역할 은 특정 방향으로의 빔 지향에 필요한 각 안테나별 전파 경로에 대해 주파수별 계산되는 위상지연을 하나의 TTD 값으로 고정하여, 주파수별 빔 편이현상을 최소화 하는데 있다. TTD의 동작을 $\mathrm{L}$ 대역에 배치함으로써, 광각에 따 른 긴 시간지연으로 인해 발생할 수 있는 신호 품질 저하 를 최소화 하였다. 16 개 단위의 안테나 내부에는 $\mathrm{Ku}$ 대역 에서 위상 천이기를 이용한 방식을 사용하였으며, 이를 결합한 신호인 L대역에서는 TTD를 이용하여 시간지연을 수행하는 방법으로, 시간 지연에 따른 손실감소 및 분산 배치로 제어회로를 간소화할 수 있다 ${ }^{[12] ~[14] . ~} 100 \mathrm{ps,} 200$ ps, $400 \mathrm{ps}, 800 \mathrm{ps}, 1,600 \mathrm{ps}$ 의 5 bit 분해능을 갖도록 TTD 를 설계하였다. TTD 소자의 시간지연은 각각 TTD 소자 전 후에 위치하는 RF 스위치를 제어하여 이루어진다. 모든 $\mathrm{RF}$ switch가 단락되면 TTD를 우회하는 경로를 통해 시간 지연이 발생하지 않도록 설계하였다. 설계된 5bit TTD 구 성도를 그림 7에 나타내었다.

시뮬레이션을 통해 수신 위상배열안테나의 빔 편이 성 능을 비교하여 그림 8 에 나타내었다. 위상천이기만 사용 할 경우, $500 \mathrm{MHz}$ 주파수 대역에서 앙각 $60^{\circ}$ 지향 시 약

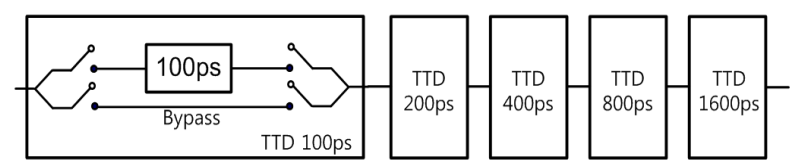

그림 7. 5bit TTD 구조도

Fig. 7. Configuration block diagram of 5 bit TTD. 
$2^{\circ}$ 의 빔 지향오차를 나타내지만, 위상천이기와 $\mathrm{TTD}$ 를 동 시 사용할 경우 빔 편이오차가 발생하지 않음을 확인하 였다. ${ }^{[10]}$

$\mathrm{Ku}$ 대역에서 L대역으로의 주파수 변환을 위해 PLL이 포함된 집적화된 소자를 사용하였다. 이를 통해 $25 \mathrm{MHz}$ 의 기준신호의 인가만으로 Ku대역으로 주파수 변환을 할 수 있으므로, 회로 설계 구성을 간략히 하여 MLB를 소형 구성 및 전력 소모 감소시킬 수 있다. 타일에서 주파수 변 환 소자는 V\&H-pol 각각 4개 사용되었다.

\section{2-5. 2차 MLB 설계}

2차 MLB의 주요 기능은 $\mathrm{MLB}$ 부터 전달된 $\mathrm{L}$ 대역 $\mathrm{V} \&$ $\mathrm{H}-\mathrm{pol}$ 각각 4 개의 신호를 4:1 결합기를 이용하여 V \& $\mathrm{H}-\mathrm{pol}$ 각각 1 개 생성한다. 약 $-77 \mathrm{dBm}$ 신호가 인가되어 $-50 \mathrm{dBm}$ 출력을 얻도록 설계하였다. 또한 2차 $\mathrm{MLB}$ 에서 $\mathrm{RF}$ 보드 내부의 위상 천이기 및 1 차 MLB의 TTD 제어 신 호를 $\mathrm{MCU}$ 를 통해 생성 및 전달한다.
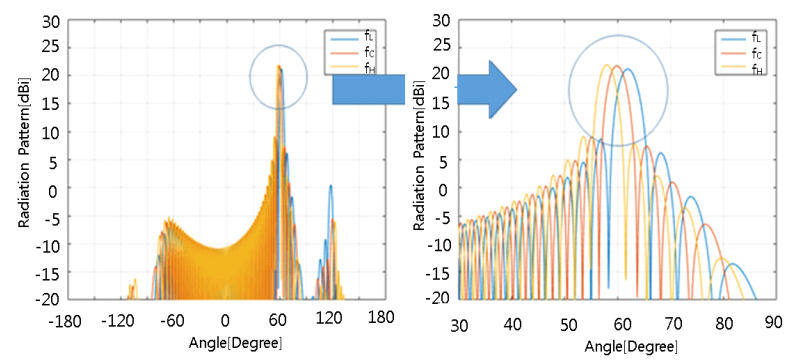

(a) 위상천이기 사용 시

(a) Simulated beam squint error with only PS
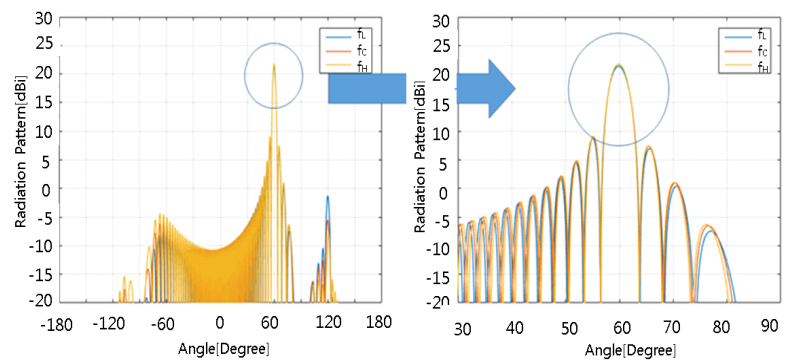

(b) 위상천이기, TTD 사용 시

(b) Simulated beam squint error with PS and TTD

그림 8. 빔 편이 오차 시뮬레이션

Fig. 8. Simulation results of beam squint error.

\section{III. 타일형 수신 위상배열 안테나의 제작 및 측정}

\section{3-1 타일형 수신 위상배열 안테나 제작}

타일형 수신배열 안테나는 $33 \times 96 \times 96 \mathrm{~mm}^{3}$ 의 크기와 약 $250 \mathrm{~g}$ 무게(하우징 포함)를 갖도록 설계되었다. 안테나 동 작을 위하여 $5 \mathrm{~V}, 3.3 \mathrm{~V}, 0.5 \mathrm{~V},-3 \mathrm{~V}$ 의 전원이 사용되며, 총 소모 전력은 약 $25 \mathrm{~W}$ 수준이다. 그림 9는 제작된 타일 형 수신 위상배열안테나를 나타낸다.

타일형 안테나는 높은 집적도로 인해 발열 문제가 심 각하다. 이를 고려하지 않으면 수신 잡음이 증가하고, 수 신 이득이 감소하며, 소모 전력이 증가하여 타일형 안테 나의 목표 성능 만족이 어려워진다. 이를 해결하기 위해 본 타일 안테나에서는 공랭식 방열을 적용하였다. 타일 외부 에 12 개의 공기 인입 및 배출을 위한 구조를 적용하여 공 기의 흐름이 가능하도록 하여 발생하는 열을 제거하는 방식이다. 방열 구조를 적용하지 않았을 때 $80^{\circ} \mathrm{C}$ 이상의 내부 동작 온도를 확인하였다. 방열구조를 적용 시 수신 타일 안테나의 동작온도를 $40^{\circ} \mathrm{C}$ 수준으로 유지하며, 정상 동작 시킬 수 있었다.

\section{3-2 타일형 수신 위상배열 안테나 성능시험 구성}

타일형 수신 위상배열안테나의 성능시험을 위해서는 $\mathrm{Ku}$ 대역 안테나 스캐너, 입출력 신호분석기(network analyzer), $25 \mathrm{MHz}$ 기준 클럭 공급 및 전원 공급이 필요하다. 또한, 설계된 수신 타일은 $\mathrm{Ku}$ 대역 신호 입력과 L대역 출 력이므로, network analyzer로 분석하기 위해서 타일 출력

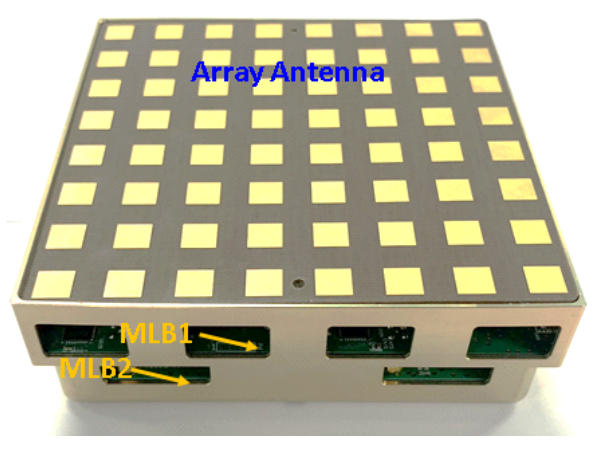

그림 9. 타일형 수신 위상배열 안테나

Fig. 9. Manufactured tile type Rx phased array antenna. 


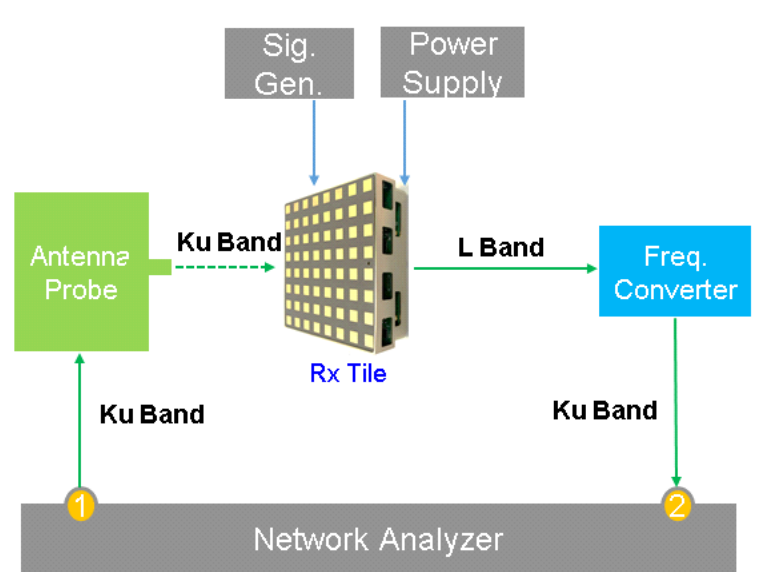

그림 10. 타일형 수신 안테나 성능시험 구성도

Fig. 10. Measurement set-up of Rx tile array antenna.

인 L대역을 $\mathrm{Ku}$ 대역으로 변환하는 주파수 변환모듈을 추 가로 필요하다. 안테나 패턴 측정을 위해서, 타일형 안테 나의 면적 4 배 이상의 근접전계를 측정할 수 있는 포지셔 너 및 스캐너를 사용하였다. 안테나 성능시험 구성도를 그림 10에 나타내었다. 성능시험시 사용한 네트워크 분석 기 및 신호발생기는 keysight의 E8363B와 E8257D를 사용 하였다. 안테나 스캐너 및 $2 \mathrm{D}, 3 \mathrm{D}$ 빔 패턴 측정 프로그램 은 (주)엠티지의 VWNF 장비를 사용하였다.

\section{3-3 타일형 수신 위상배열 안테나 보정}

위상배열 안테나는 배열소자, 능동회로 간 공정 및 성 능오차 및 안테나 상호 간섭현상으로 인해 필연적으로 오차가 발생하며, 이는 원하지 않는 빔 성능 저하를 가져 온다. 따라서 성능시험 전 안테나의 진폭 및 위상에 관한 보정이 필요하다. 본 타일형 수신 위상배열 안테나에서는 안테나 스캐너를 이용하여 근접전계를 측정한 후 개구면 표면의 안테나별 위상을 도출한다. 도출된 위상을 서로 비교하여 그 차이를 위상천이기로 보상하여 안테나 간 보정하였다. 이때 위상은 $22.5^{\circ}$ 의 위상천이기 분해능 범 위내로 보정된다. 그림 11 에서 근접전계 측정된 안테나 보상 전, 후의 결과를 나타내었다. 그림 11의 왼쪽의 위상 측정은 오른쪽 근접전계 위상분포 $\left(f_{c}\right)$ 의 붉은 점선에 해당 되는 주파수별 결과를 나타낸다. 보정전은 위상오차 최대 지점이 약 $180^{\circ}$ (녹색 청색)을 나타내고 있지만, 보정 후

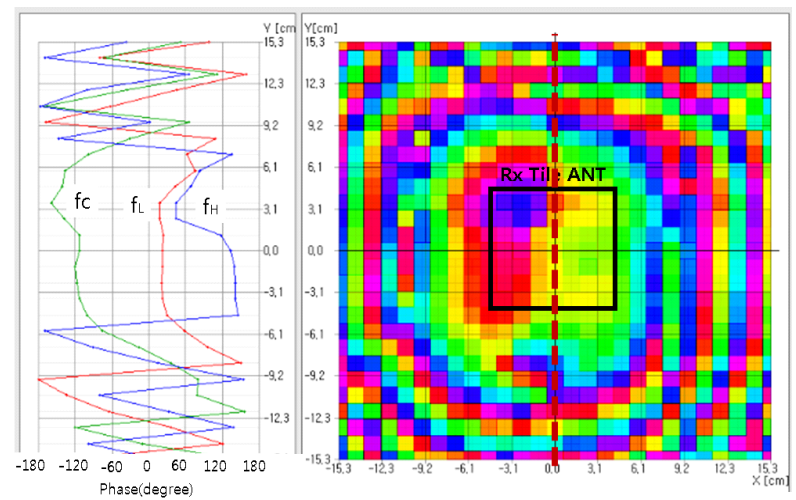

(a) 타일 안테나 보정 전 위상

(a) Before tile antenna calibration

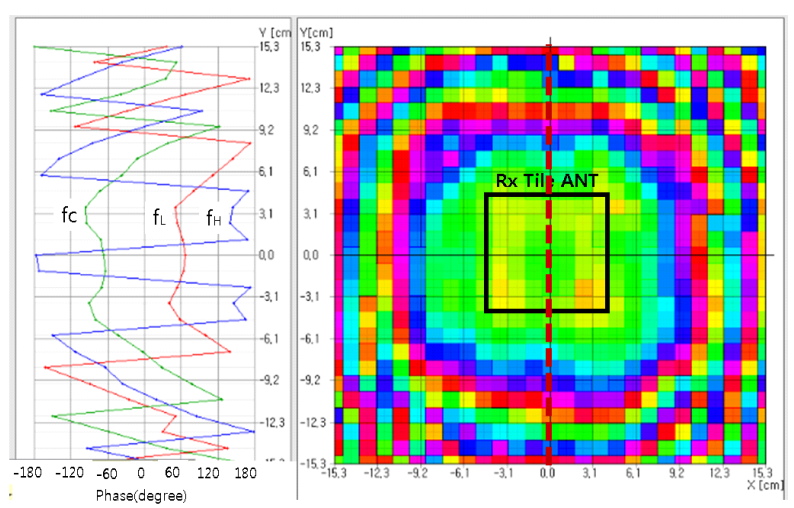

(b) 타일 안테나 보정 후 위상

(b) After tile antenna calibration

그림 11. 수신 타일 보정을 위한 근접전계

Fig. 11. Measured near-field scan results of Rx tile antenna.

타일안테나 위상이 $22.5^{\circ}$ (녹색) 이내로 조정됨을 확인할 수 있다.

\section{3-4 타일형 수신 위상배열 안테나 성능시험 결과}

그림 12는 수신 타일 안테나 V \& H-pol의 bore-sight 및 앙각 $40^{\circ}$ 지향 성능시험 결과를 나타낸다. 주파수 변환 모듈의 손실과 케이블 손실, MLB의 이득을 제외한 실제 안테나 보드의 이득은 중심주파수에서 H-pol $23.17 \mathrm{~dB}$ 이 며, V-pol은 $25.2 \mathrm{~dB}$ 이다. 이때 빔폭은 H-pol 11.8 , V-pol $12.7^{\circ}$ 로 측정되었다.

빔 지향 정확도 및 빔 지향오차를 확인하기 위하여 방 

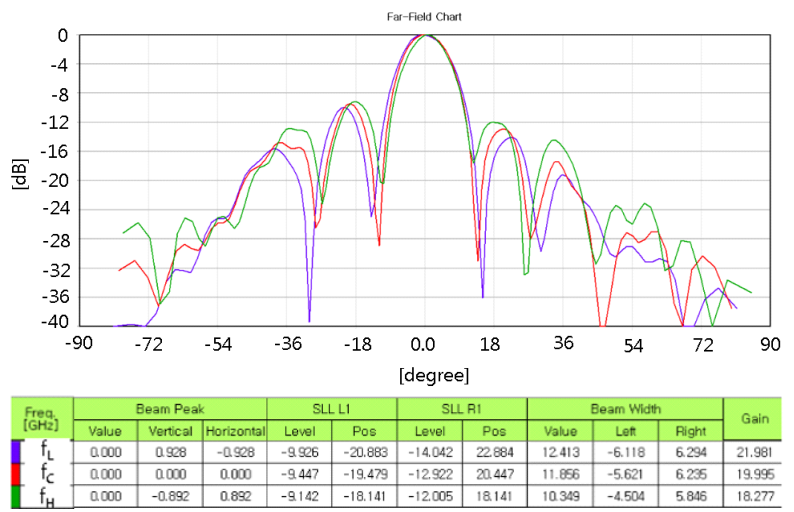

(a) H-pol, bore-sight 측정 결과

(a) Measured result in H-pol, bore-sight
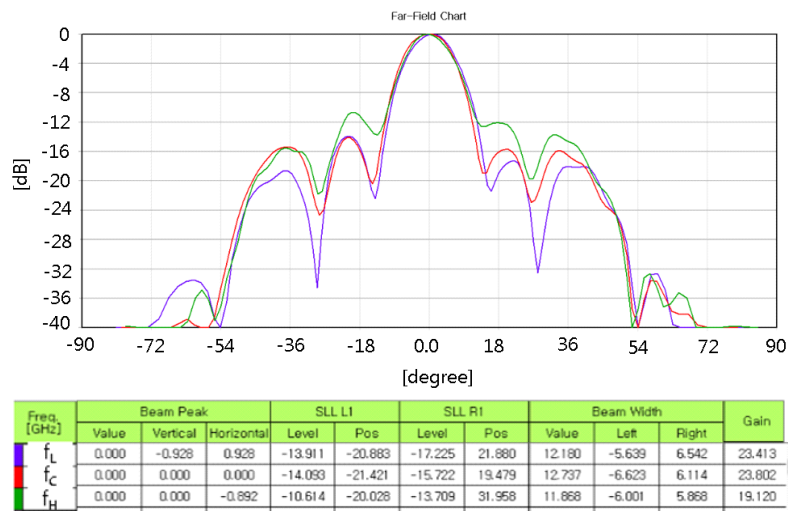

(b) V-pol, bore-sight 측정 결과

(b) Measured result in V-pol, bore-sight

그림 12. 타일형 수신 위상배열 안테나이득 측정 결과

Fig. 12. Measured results of antenna gain in $\mathrm{Rx}$ tile antenna.

위각 $0^{\circ}$, 앙각 $40^{\circ}$ 방향으로 지향 시험하였다. 그림 13에 빔 지향시험 2D cut 결과를 나타내었으며, 표 2에 빔 지향 시험 결과를 정리하였다.

$500 \mathrm{MHz}$ 대역폭에 따른 빔 편이 오차는 H-pol $0.918^{\circ}$, V-pol $0.681^{\circ}$ 수준을 나타내었다. 이는 빔 지향을 위한 $\mathrm{Ku}$ 대역 위상천이기와 L대역 TTD의 결합을 통해 낮은 빔 편 이오차를 보이며 정상 동작함을 확인할 수 있다. 빔 지향 정확도는 최대 $2.7^{\circ}$ 의 오차를 나타내었다. 이는 향후 안테 나 배열 수 증가 및 안테나 추가 보정을 통해 이의 개선 이 가능하다. 그림 14에서는 H-pol의 bore-sight 및 방위각 $0^{\circ}$, 앙각 $40^{\circ}$ 지향을 확인할 수 있는 안테나 $3 \mathrm{D}$ 패턴 측정
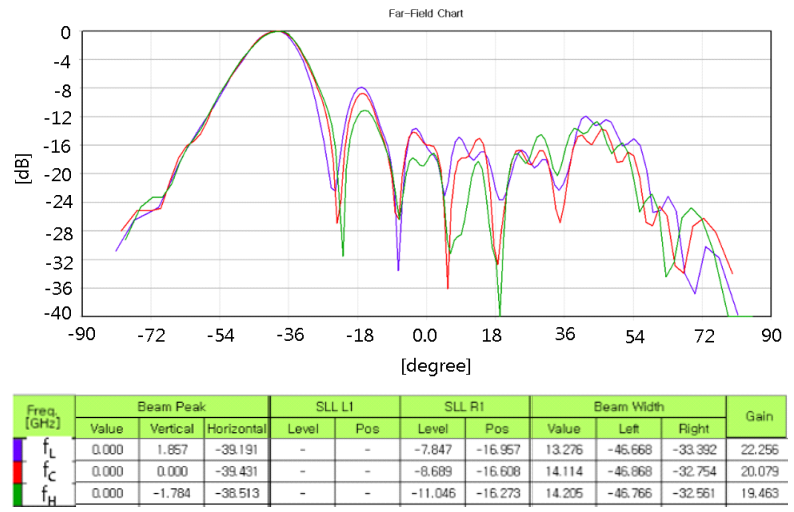

(a) H-pol, phi $0^{\circ}$, theta $40^{\circ}$ 측정 결과

(a) Measured result in phi $0^{\circ}$, theta $40^{\circ}$
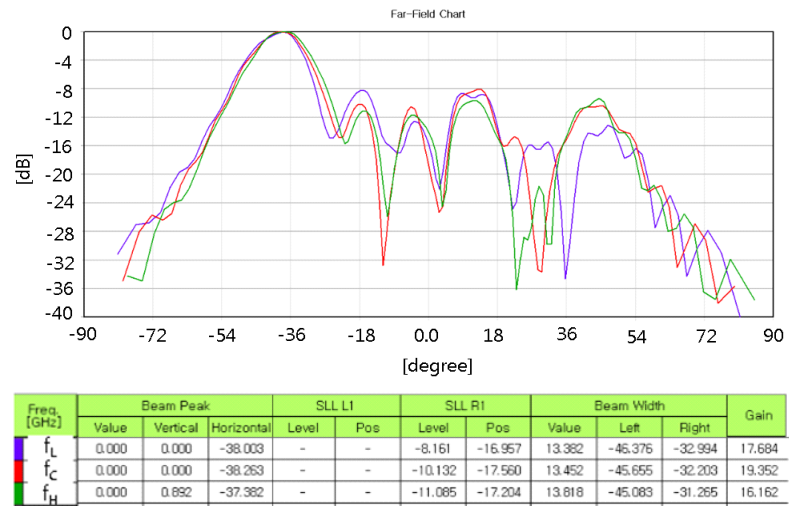

(b) V-pol, phi $0^{\circ}$, theta $40^{\circ}$ 측정 결과

(b) Measured result in phi $0^{\circ}$, theta $40^{\circ}$

그림 13. 타일형 수신 위상배열 안테나 빔지향 측정 결과

Fig. 13. Measured results of beam steering in Rx tile antenna.

표 2. 빔 지향각 및 빔 편이 오차 측정결과

Table 2. Measured results of beam steering angle and beam squint error.

\begin{tabular}{|c|c|c|c|c|}
\hline Freq. & $\begin{array}{c}\text { Beam } \\
\text { steering } \\
\text { angle } \\
\text { (H-pol) }\end{array}$ & $\begin{array}{c}\text { Beam } \\
\text { steering } \\
\text { angle } \\
\text { (V-pol) }\end{array}$ & $\begin{array}{c}\text { Beam } \\
\text { pointing } \\
\text { error } \\
\text { (H-pol) }\end{array}$ & $\begin{array}{c}\text { Beam } \\
\text { pointing } \\
\text { error } \\
\text { (V-pol) }\end{array}$ \\
\hline$f_{L}$ & $39.191^{\circ}$ & $38.003^{\circ}$ & \multirow{3}{*}{$0.918^{\circ}$} & \multirow{3}{*}{$0.681^{\circ}$} \\
\hline$f_{C}$ & $39.431^{\circ}$ & $38.063^{\circ}$ & & \\
\hline$f_{H}$ & $38.513^{\circ}$ & $37.382^{\circ}$ & & \\
\hline
\end{tabular}

결과를 나타내었다. 


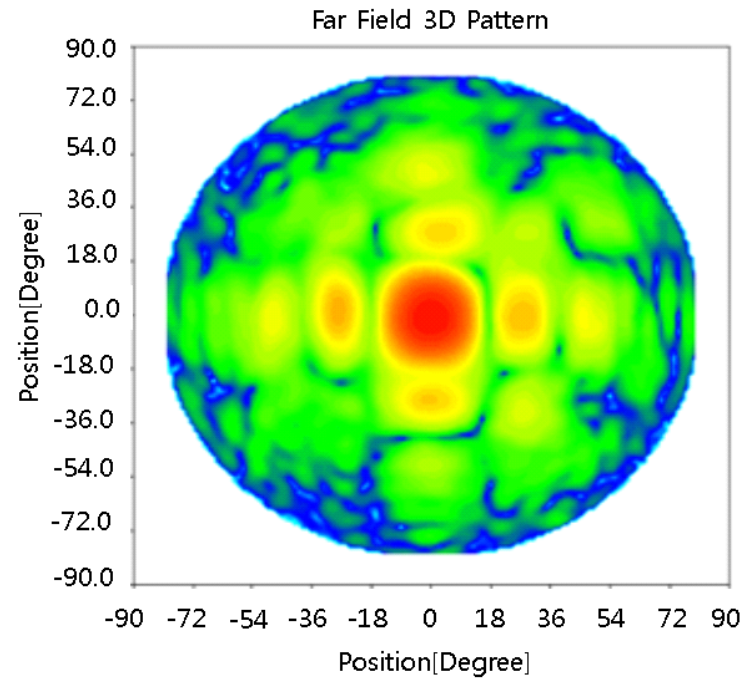

(a) Bore-sight 측정 결과(3D)

(a) Measured result in bore-sight(3D)

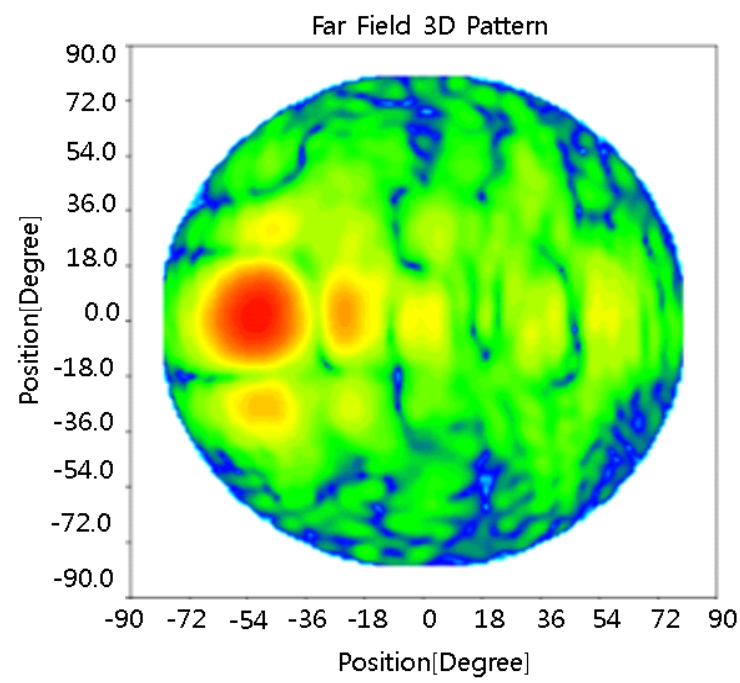

(b) Phi $0^{\circ}$ theta $40^{\circ}$ 측정 결과(3D)

(b) Measured result in phi $0^{\circ}$, theta $40^{\circ}(3 \mathrm{D})$

그림 14. 타일형 수신 위상배열 안테나 3D 측정 결과

Fig. 14. Measured results of $\mathrm{Rx}$ tile antenna in $3 \mathrm{D}$ view.

\section{$\mathrm{V}$. 결 론}

본 논문에서는 $\mathrm{Ku}$ 대역 위성 통신을 위한 타일형 수신 위상 배열안테나의 설계, 제작 및 성능시험 결과에 대해 기술하였다. 제작 및 성능시험을 통해 제안한 타일 수신 위상배열 안테나의 전기적 목표 성능을 모두 만족함을
확인하였다. 또한, 본 논문에서 제안한 타일형 안테나의 연속배열을 통해 $\mathrm{Ku}$ 대역 위성 통신용 수신 위상배열 안 테나의 구현이 가능하며, 이는 외부 형상에 돌출된 구조 가 없는 광대역 광각의 빔 편이오차가 최소화된 위성통 신용 컨포멀 안테나로의 응용 가능할 것이다.

\section{References}

[1] R. J. Mailloux, "Antenna array architecture," in Proceedings of the IEEE, vol. 80, no. 1, pp. 163-172, Jan. 1992.

[2] N. C. Currie, C. E. Brown, Principles and Applications of Millimeter-Wave Radar, Norwood, MA, Artech House, 1987.

[3] L. Josefsson, P. Persson, Conformal Array Antenna Theory and Design, Hoboken, NJ, John Wiley \& Sons, 2006.

[4] R. J. Mailloux, Phased Array Antenna Handbook, Norwood, MA, Artech House, 2007.

[5] D. Parker, D. C. Zimmermann, "Phased arrays-Part I: Theory and architecture," IEEE Transactions on Microwave Theory and Techniques, vol. 50, no. 3, pp. 678-687, Mar. 2013.

[6] H. Schippers, J. Verpoorte, A. Hulzinga, C. Roeloffzen, and R. Baggen, "Towards structural integration of airborne Ku-band satcom antenna," in 2013 7th European Conference on Antennas and Propagation(EuCAP), Gothenburg, 2013, pp. 2963-2967.

[7] M. van der Vossen, G. Voshaar, C. Roeloffzen, A. Hulzinga, and M. Iven, "Design of a highly integrated Ku-band planar broadband phased array receiver with dual polarization," in 2014 11th European Radar Conference, Rome, 2014, pp. 392-395.

[8] B. A. Kopp, M. Borkowski, and G. Jerinic, "Transmit/ receive modules," IEEE Transaction on Microwave Theory and Techniques, vol. 50, no. 3, pp. 827-834, Mar 2002.

[9] J. U. Jeong, J. H. Ryu, T. H. Ju, G. C. Kim, I. H. Park, and J. U. Seo, "Design technology of shape adaptive active phased array antenna for communication," The Magazine of the IEIE, vol. 44, no. 4, pp. 39-47, Apr. 2017. 
[10] J. S. Kot, I. M. Davis, C. Granet, and G. Pope, "Antenna concepts for Ka-band SATCOM on the move," in Military Communication and Information System 2009 Conference(MILCIS), 2009.

[11] D. Marpaung, L. Zhuang, M. Burla, C. Roeloffzen, J. Verpoorte, and H. Schippers, "Towards a broadband and squint-free $\mathrm{Ku}$ band phased array antenna system for airborne satellite communications," in Proceedings of the 5th European Conference on Antennas and Propagation(EUCAP), Rome, 2011, pp. 2623-2627.

[12] J. Jung, J. Ryu, J. Park, and J. Seo, "A study on confi-

주 태 환 [국방과학연구소/선임연구원]

https://orcid.org/0000-0002-8750-9779

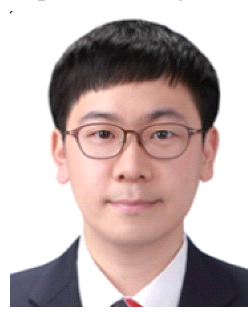

2008년 2월: 부산대학교 전기 및 전자공학 부 (공학사)

2010년 2월: 한국과학기술연구원 전기전 자공학과 (공학석사)

2014년 2월: 한국과학기술연구원 전기전 자공학과 (공학박사)

2016년 10월 현재: 국방과학연구소 선임 연구원

[주 관심분야] RF Transceiver, 데이터링크 시스템 guration of true time delay phase shifter for wideband beam steering phased array antenna," Journal of the KIMST, vol. 20, no. 3, pp. 413-420, Jun. 2017.

[13] M. Longbrake, "True time-delay beamsteering for radar," in 2012 IEEE National Aerospace and Electronics Conference(NAECON), Dayton, OH, 2012, pp. 246-249. [14] J. G. Willms, A. Ouacha, L. de Boer, and F. E. van Vliet, "A wideband GaAs 6-bit true-time delay MMIC employing on-chip digital drivers," in 2000 30th European Microwave Conference, Paris, 2000, pp. 1-4.
서 종 우 [국방과학연구소/책임연구원] https://orcid.org/0000-0001-6784-2745

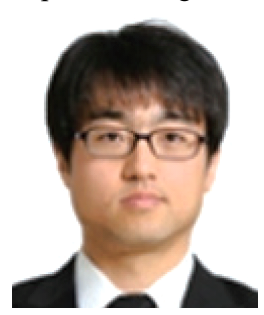

2000년 2월: 충남대학교 전파공학과 (공학 사)

2002년 2월: 충남대학교 전파공학과 (공학 석사)

2017년 2월: 충남대학교 전파공학과 (공학 박사)

2002년 1월 현재: 국방과학연구소 책임 연구원

[주 관심분야] 널링 안테나, 패턴합성 알고리즘, 컨포멀 안테나
김 기 철 [국방과학연구소/선임연구원]

https://orcid.org/0000-0003-1652-5576

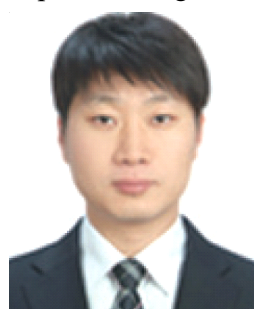

2007년 2월: 영남대학교 전자공학과 (공학사)

2011년 2월: 광주과학기술원 (공학석사)

2016년 8월: 한국과학기술연구원 전기전 자공학과 (공학박사)

2007년 1월 2008 11월: 삼성탈레스 연구

원

2016년 10월 현재: 국방과학연구소 선임

연구원

[주 관심분야] RF 회로 및 전력증폭기, 통신용 초고주파 기술 